\title{
A Lewis Pair as Organocatalyst for One-Pot Synthesis of Block Copolymers from a Mixture of Epoxide, Anhydride, and $\mathrm{CO}_{2}$
}

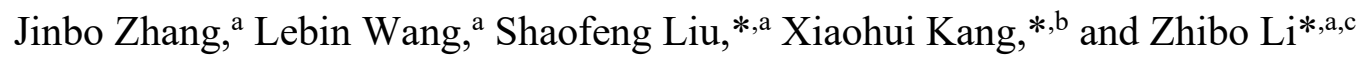

${ }^{\text {a }}$ Key Laboratory of Biobased Polymer Materials, College of Polymer Science and Engineering, Qingdao University of Science and Technology, Qingdao, 266042, China

${ }^{\mathrm{b}}$ College of Pharmacy, Dalian Medical University, Dalian 116044, China

${ }^{\mathrm{c}}$ College of Chemical Engineering, Qingdao University of Science and Technology, Qingdao, 266042, China

*Corresponding Author: E-mail: shaofengliu@qust.edu.cn; kangxh@dmu.edu.cn and zbli@qust.edu.cn 
Table S1. Copolymerization of $\mathrm{CHO} / \mathrm{PA} / \mathrm{CO}_{2}$ with $\mathrm{PPNCl} / \mathrm{TEB}{ }^{a}$

\begin{tabular}{|c|c|c|c|c|c|c|c|}
\hline run & $\begin{array}{c}{[\mathrm{CHO}] /[\mathrm{PA}] /} \\
{[\mathrm{PPNCl}] /[\mathrm{TEB}]}\end{array}$ & $\mathrm{CO}_{2}(\mathrm{MPa})$ & $t(\mathrm{~min})$ & $\begin{array}{c}\mathrm{PA} \mathrm{conv}^{b} \\
(\%)\end{array}$ & $\begin{array}{c}M_{\mathrm{n} . \mathrm{GPC}^{c}} \\
(\mathrm{kDa})\end{array}$ & $\Xi^{c}$ & ${\text { PE or } \mathrm{PC}^{d}}$ \\
\hline 1 & $500 / 50 / 1 / 0$ & 0 & 30 & 9 & n.d. $^{e}$ & n.d. $^{e}$ & $\mathrm{PE}$ \\
\hline 2 & $500 / 50 / 1 / 0.1$ & 0 & 30 & 22 & 2.7 & 1.17 & $\mathrm{PE}$ \\
\hline 3 & $500 / 50 / 1 / 0.5$ & 0 & 30 & $>99$ & 8.9 & 1.10 & $\mathrm{PE}$ \\
\hline 4 & $500 / 50 / 1 / 1$ & 0 & 300 & 95 & 7.2 & 1.30 & $\mathrm{PE}$ \\
\hline 5 & $500 / 50 / 1 / 2$ & 0 & 300 & 30 & 3.0 & 1.33 & $\mathrm{PE}$ \\
\hline 6 & $500 / 50 / 1 / 2$ & 0 & 1440 & $>99$ & 5.7 & 1.35 & $\mathrm{PE}$ \\
\hline 7 & $500 / 0 / 1 / 0.5$ & 1 & 60 & - & 5.0 & 1.09 & $\mathrm{PC}$ \\
\hline 8 & $500 / 0 / 1 / 2$ & 1 & 30 & - & 6.2 & 1.13 & $\mathrm{PC}$ \\
\hline 9 & $500 / 50 / 1 / 2$ & 1 & 30 & $<1$ & 4.5 & 1.19 & $\mathrm{PC}$ \\
\hline
\end{tabular}

${ }^{a}$ Conditions: $0.028 \mathrm{mmol}$ of PPNCl, $14 \mathrm{mmol}$ of $\mathrm{CHO}(1.4 \mathrm{~mL}), 1.4 \mathrm{~mL}$ of THF, $80{ }^{\circ} \mathrm{C} .{ }^{b}$ Determined by ${ }^{1} \mathrm{H}$ NMR. ${ }^{c}$ Determined by GPC at $40{ }^{\circ} \mathrm{C}$ in THF relative to polystyrene standards. ${ }^{d}$ Polyester (PE) or Polycarbonate (PC). ${ }^{e}$ Not determined. 


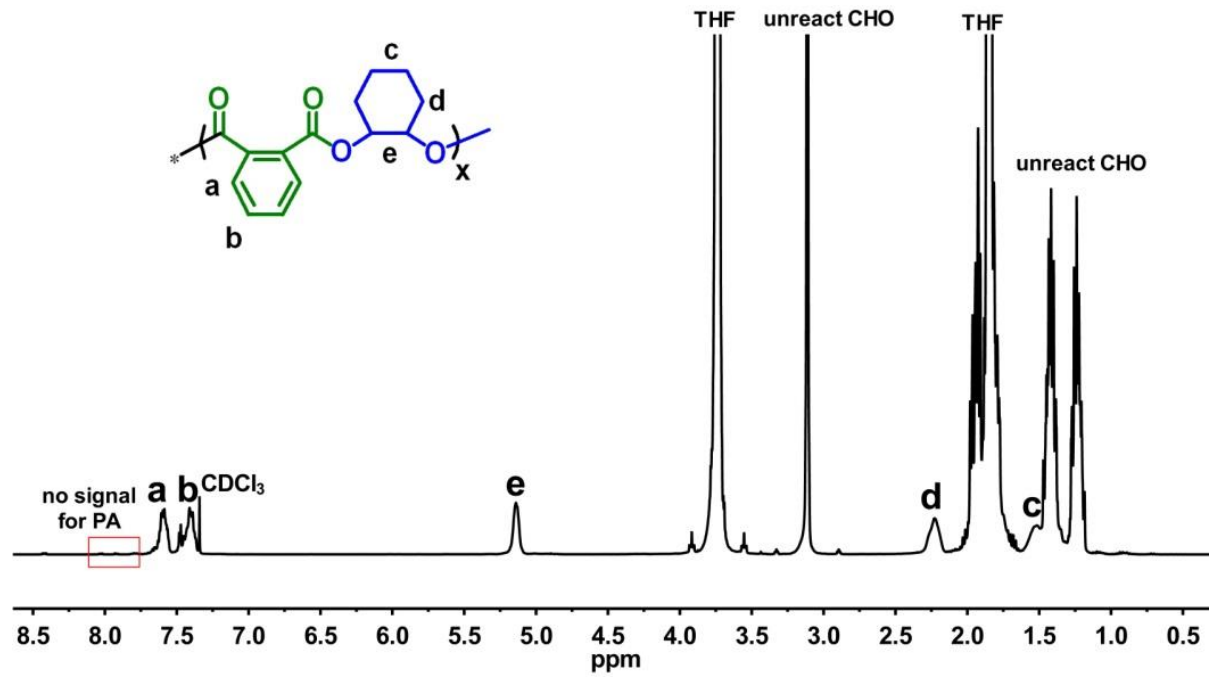

Figure S1. ${ }^{1} \mathrm{H}$ NMR spectrum $\left(\mathrm{CDCl}_{3}\right)$ of the crude reaction mixture (Table 1 run 1 ).

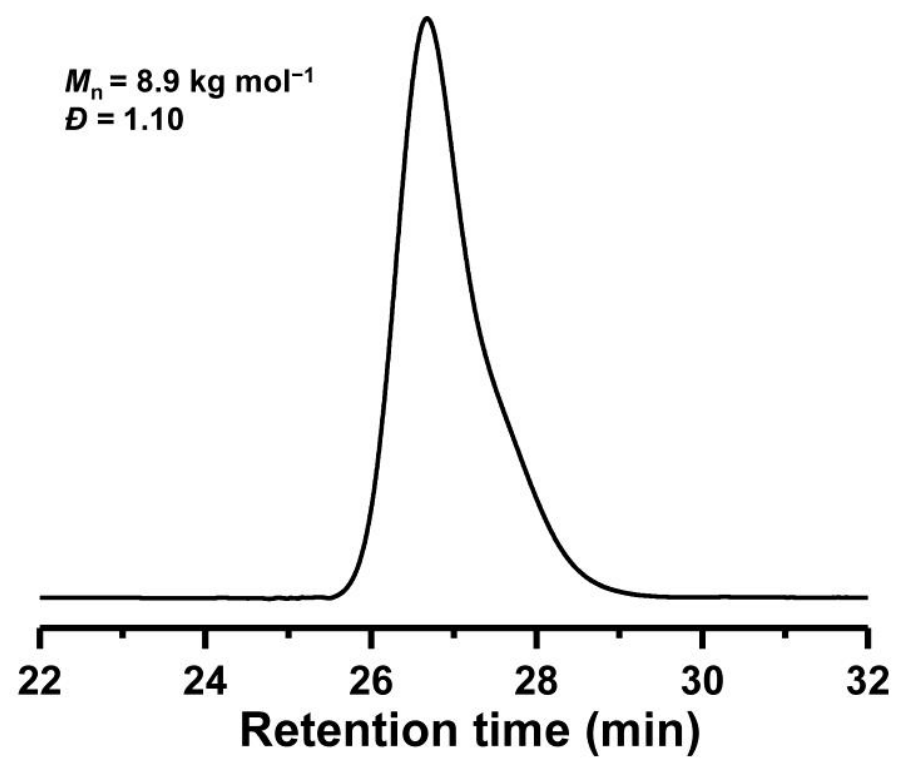

Figure S2. GPC trace of the crude reaction mixture (Table 1 run 1). 
$\mid \mathrm{CDCl}_{3}$

$\mathrm{CDCl}_{3}$<smiles>[X]C(C)(C)O[C@@H]1CCCC[C@H]1OC(=O)c1ccccc1C(C)=O</smiles>

b
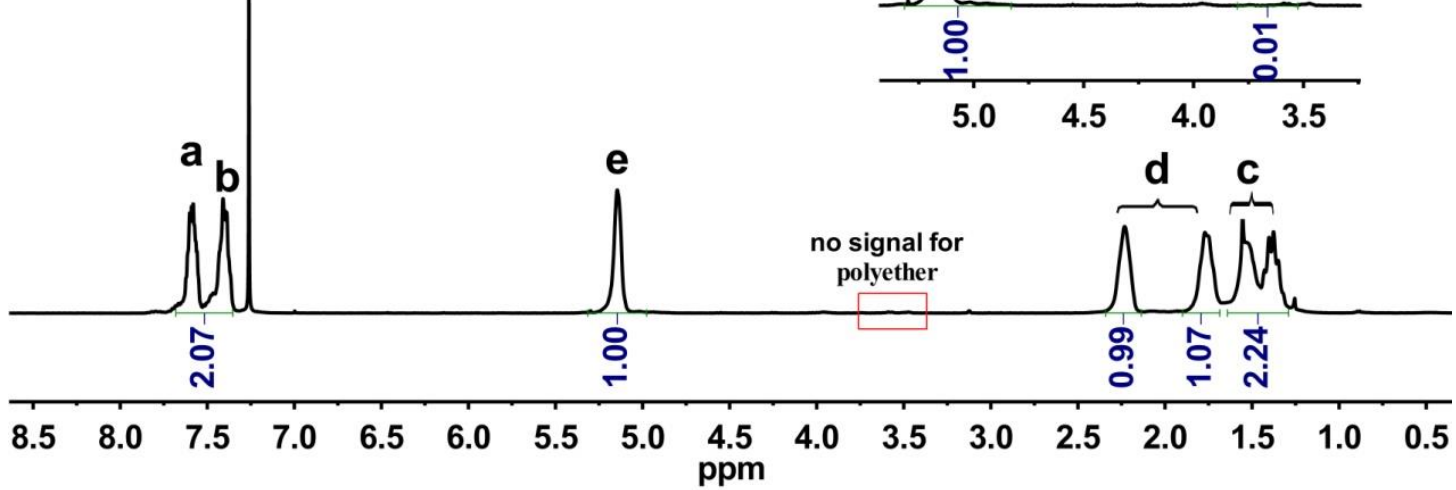

Figure S3. ${ }^{1} \mathrm{H}$ NMR spectrum $\left(\mathrm{CDCl}_{3}\right)$ of poly(PA-alt-CHO) (Table 1 run 1).

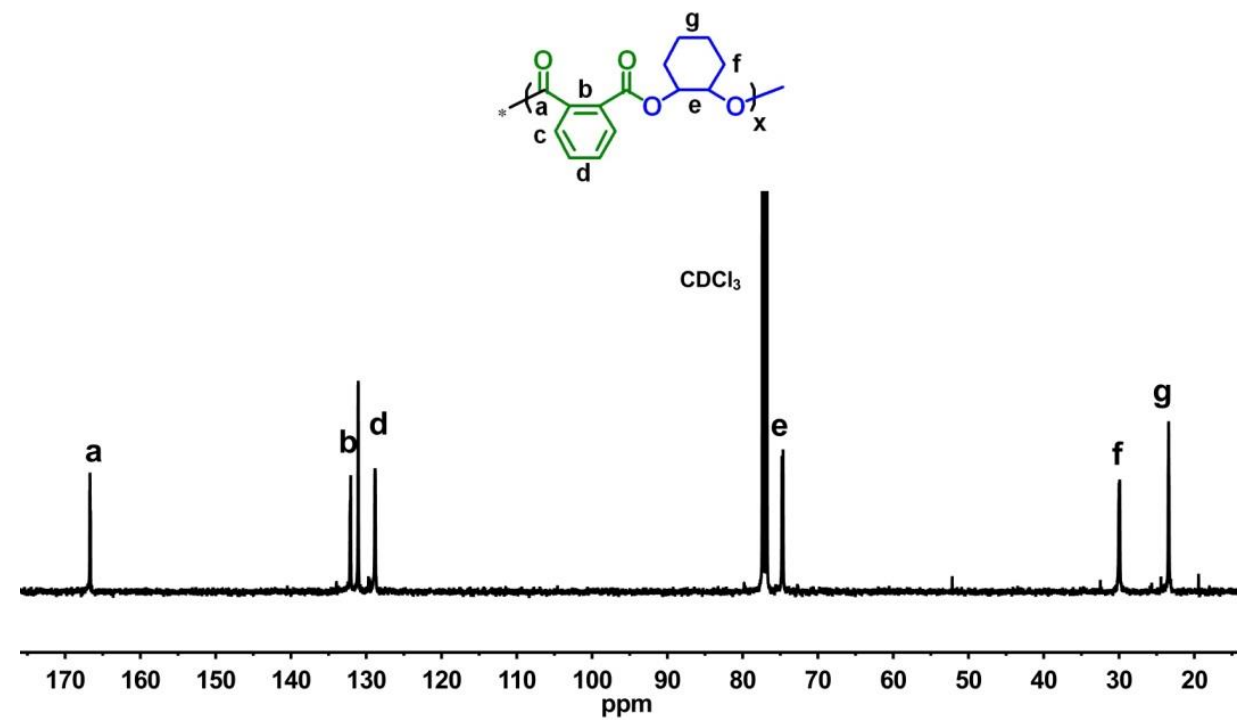

Figure S4. ${ }^{13} \mathrm{C}$ NMR spectrum $\left(\mathrm{CDCl}_{3}\right)$ of poly(PA-alt-CHO) (Table 1 run 1). 


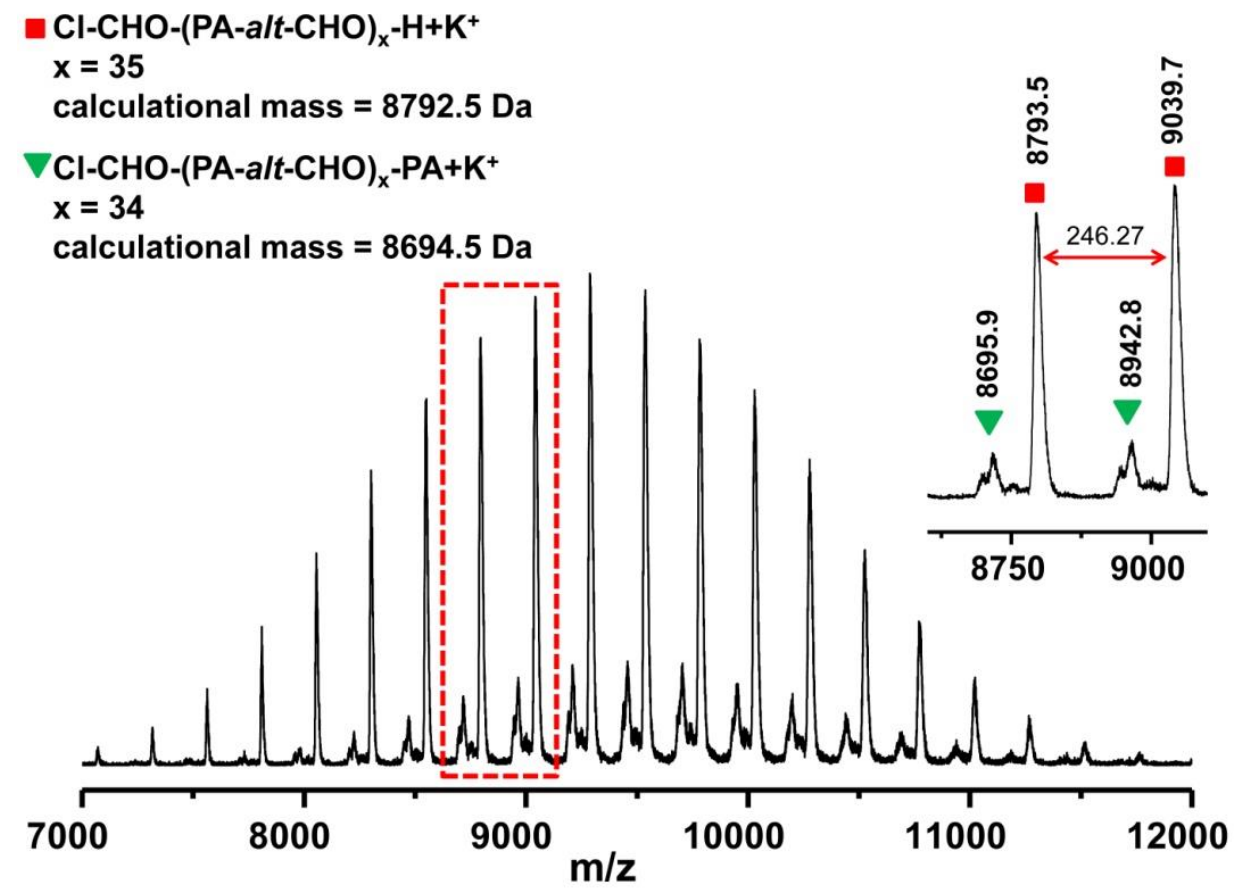

Figure S5. MALDI TOF mass spectrum of poly(PA-alt-CHO) synthesized with PPNCl/TEB (Table 1 run 1).

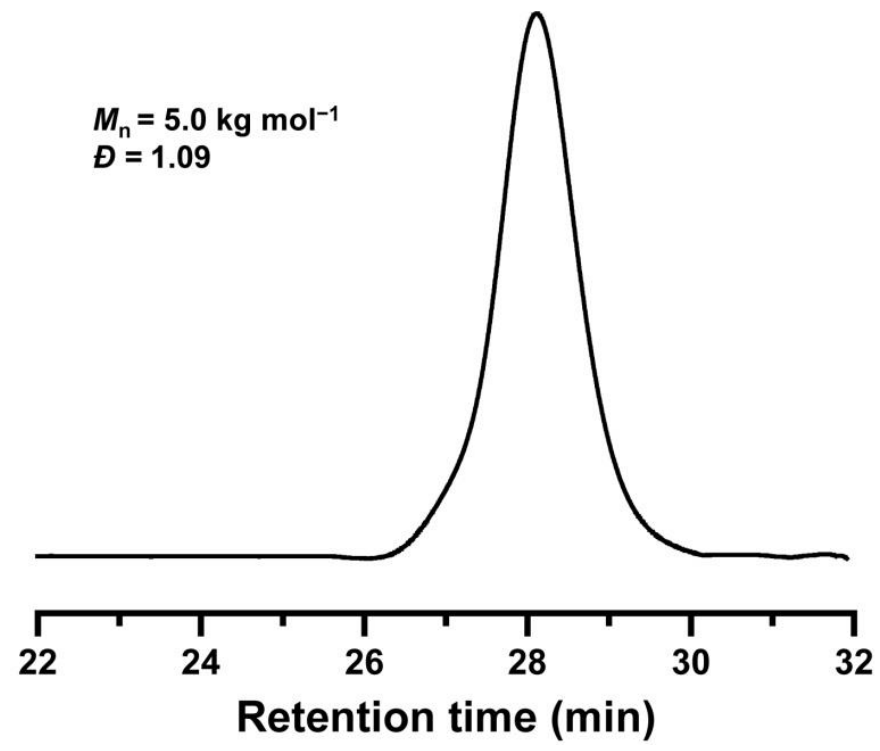

Figure S6. GPC trace of PCHC (Table 1 run 2). 


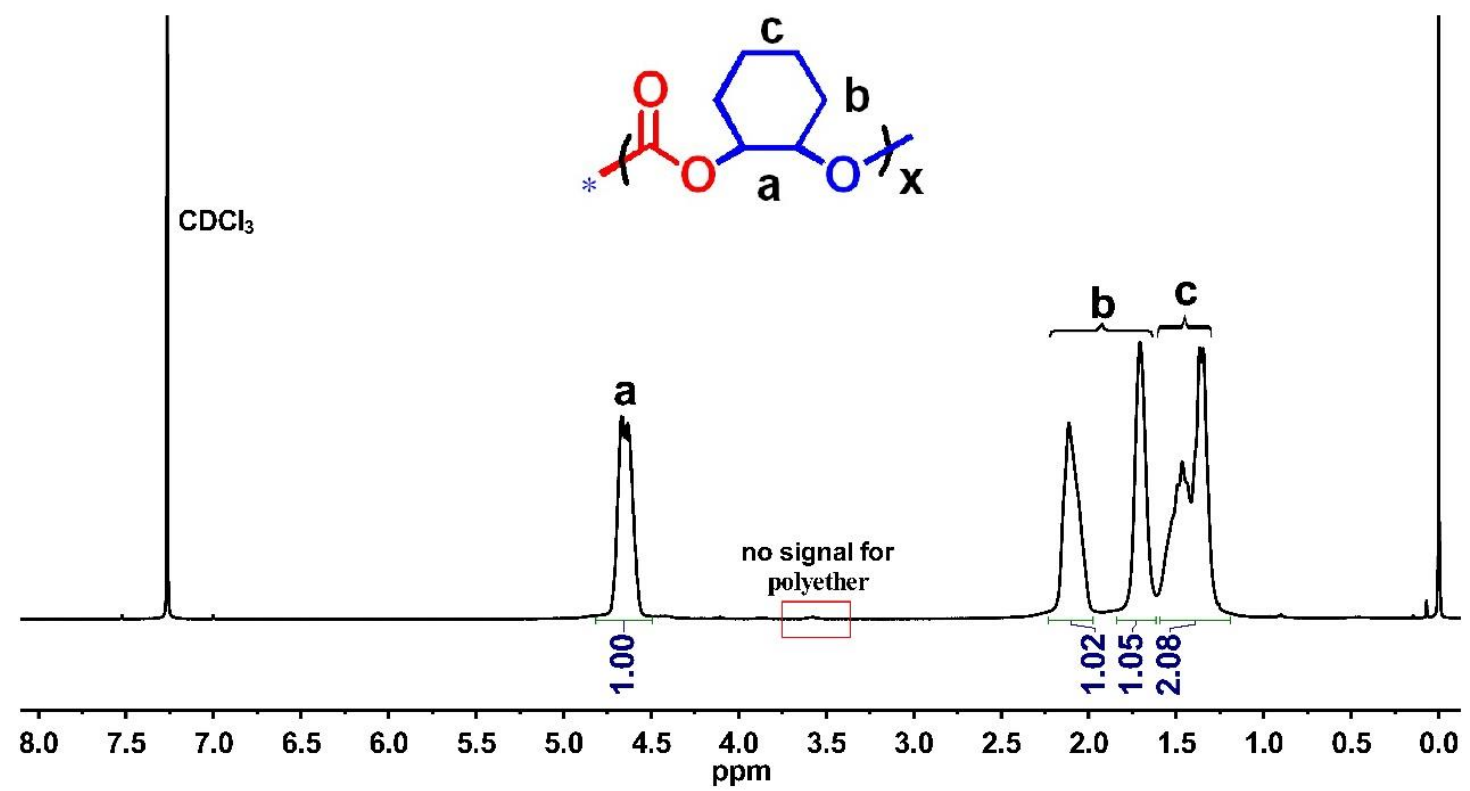

Figure S7. ${ }^{1} \mathrm{H}$ NMR spectrum $\left(\mathrm{CDCl}_{3}\right)$ of $\mathrm{PCHC}$ (Table 1 run 2$)$.

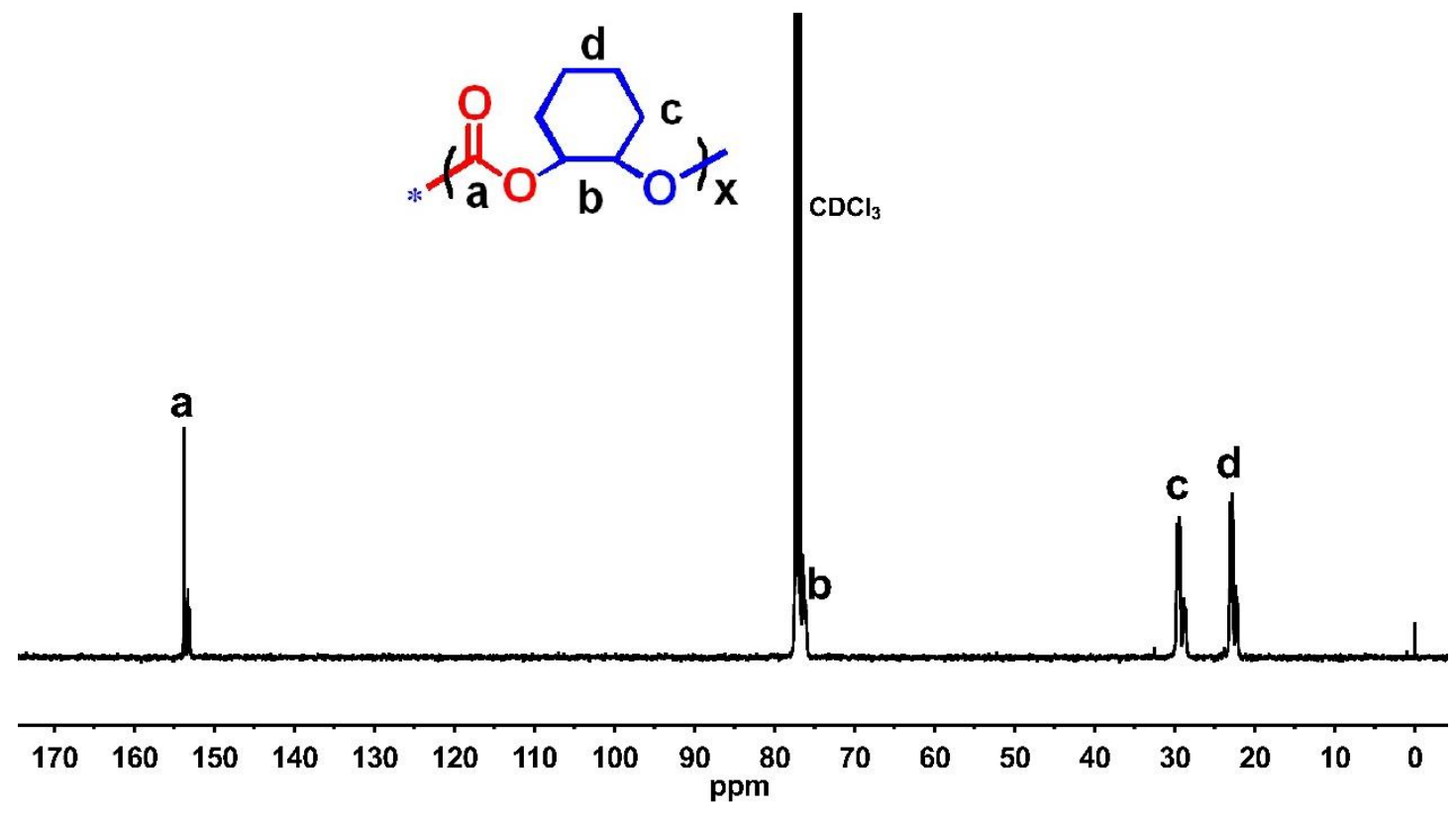

Figure S8. ${ }^{13} \mathrm{C}$ NMR spectrum $\left(\mathrm{CDCl}_{3}\right)$ of $\mathrm{PCHC}$ (Table 1 run 2$)$. 


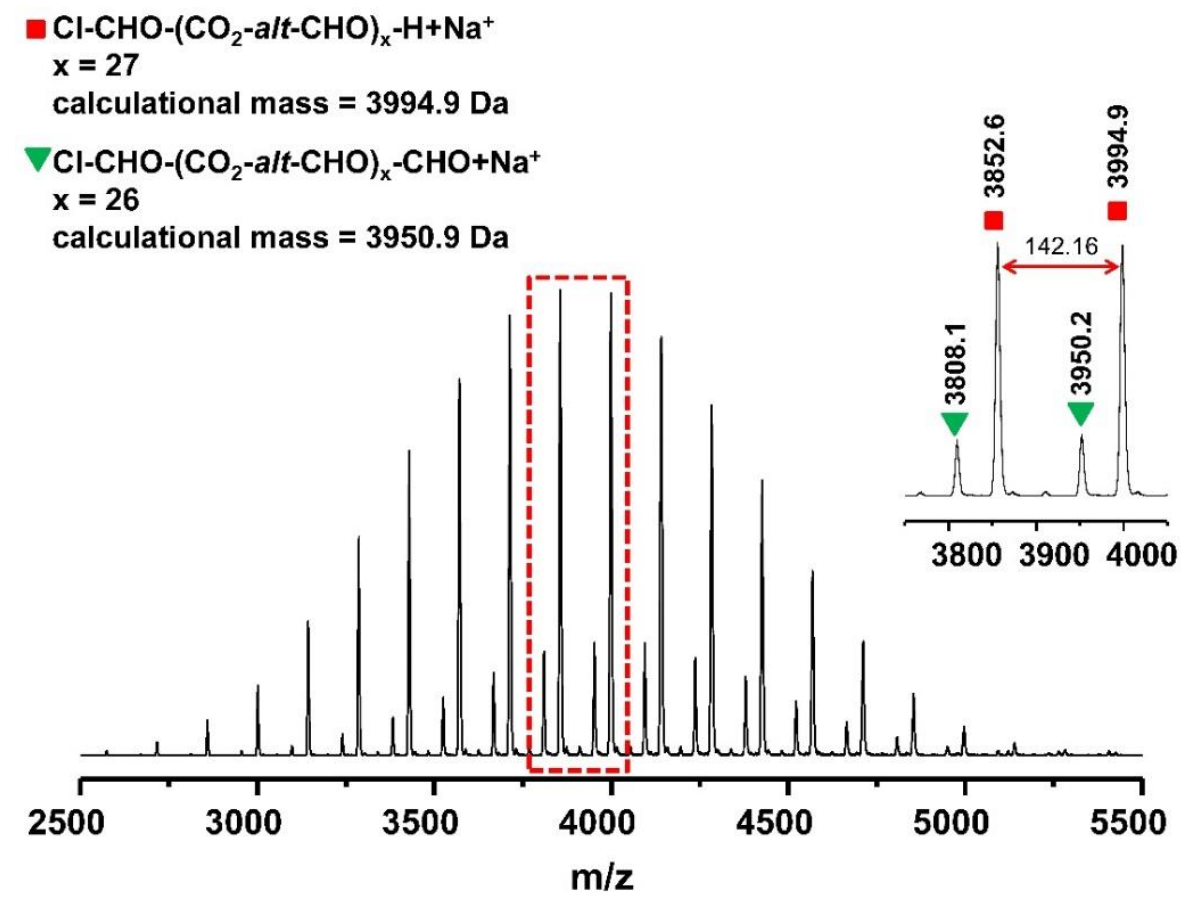

Figure S9. MALDI TOF mass spectrum of PCHC synthesized with PPNCl/TEB (Table 1 run 2).

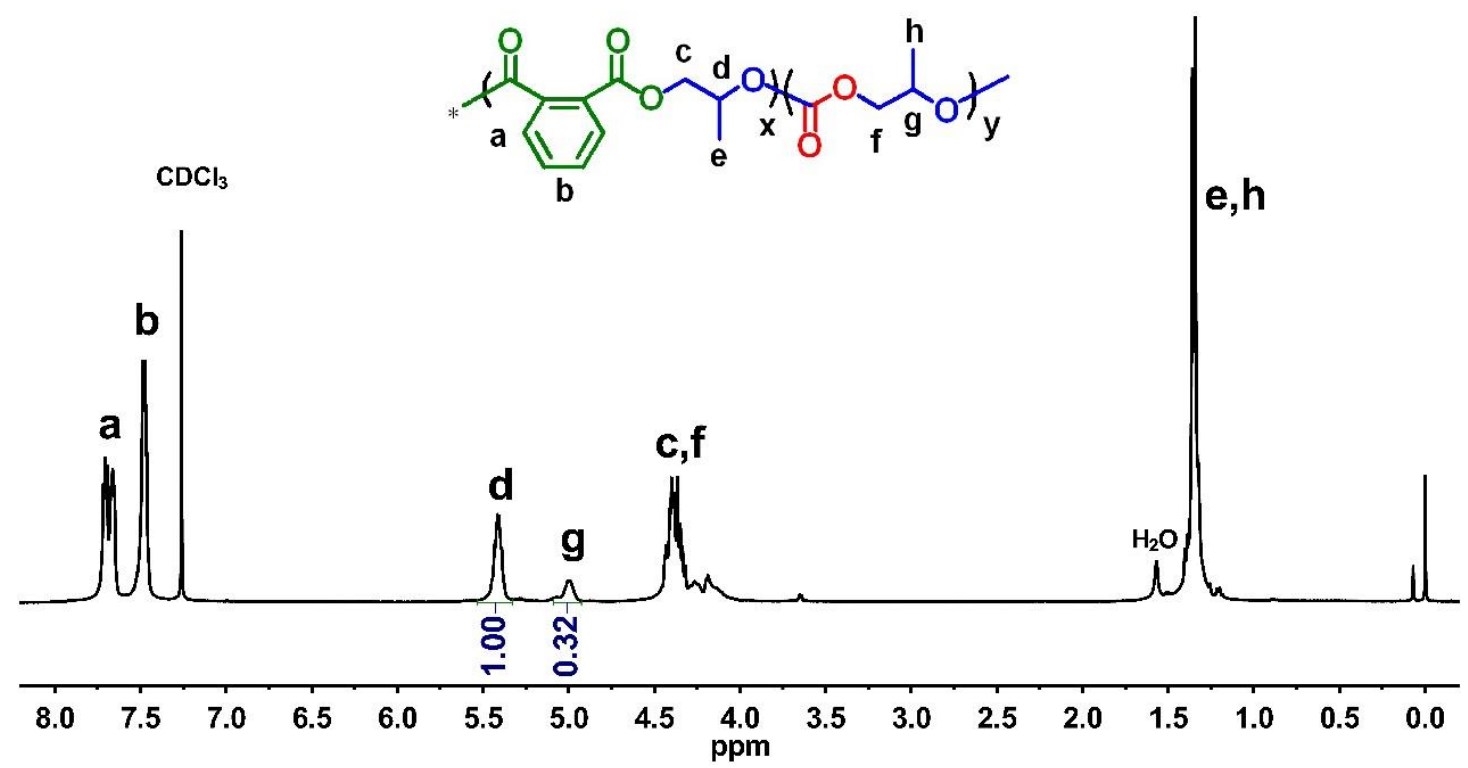

Figure S10. ${ }^{1} \mathrm{H}$ NMR spectrum $\left(\mathrm{CDCl}_{3}\right)$ of poly(PA-alt-PO)-b-PPC obtained in the one-step route (Table 1 run 11). 


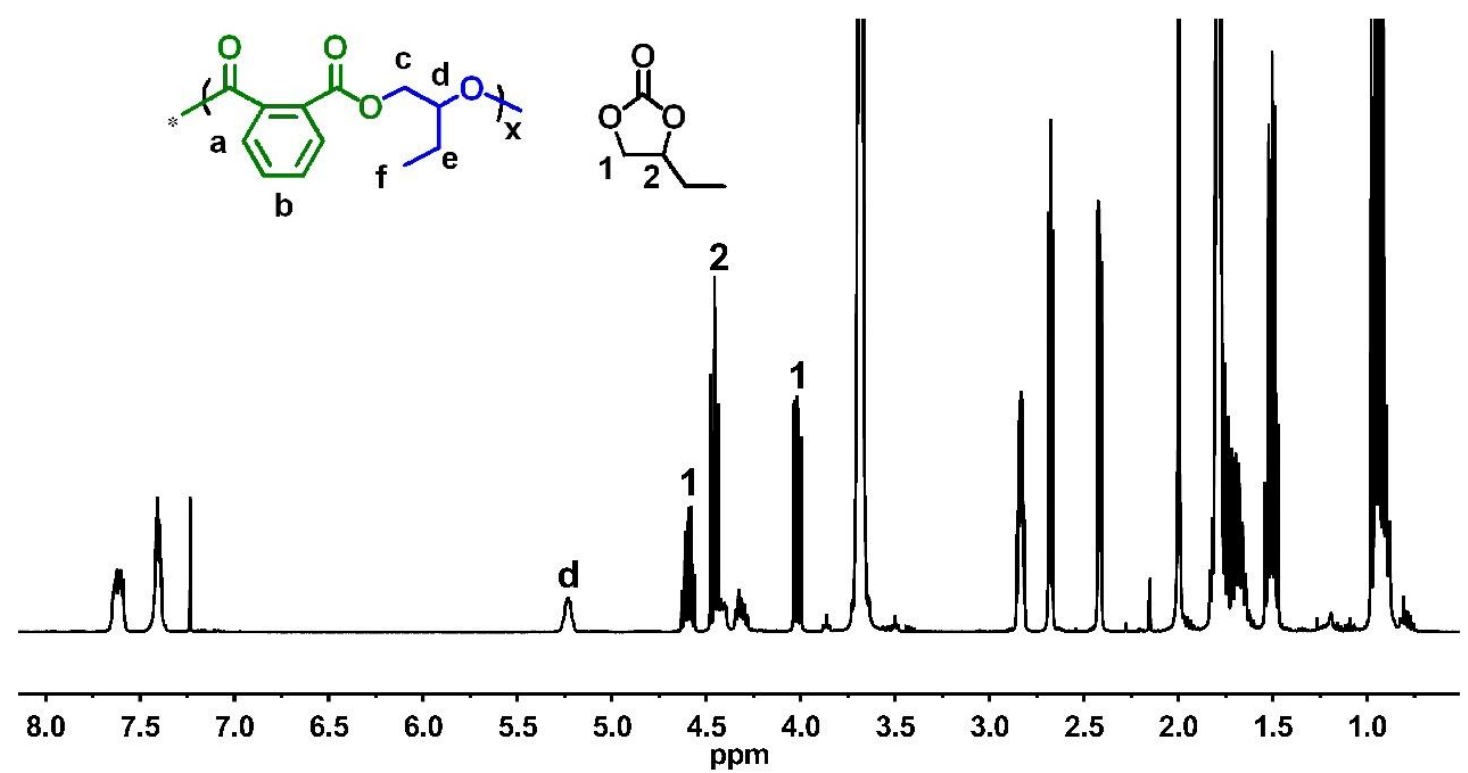

Figure S11. ${ }^{1} \mathrm{H}$ NMR spectrum $\left(\mathrm{CDCl}_{3}\right)$ of the crude reaction mixture in the copolymerization of $\mathrm{BO} / \mathrm{PA} / \mathrm{CO}_{2}\left(\mathrm{BO} / \mathrm{PA} / \mathrm{PPNCl} / \mathrm{TEB}=500 / 50 / 1 / 0.5,1 \mathrm{MPa}\right.$ of $\mathrm{CO}_{2}$ at $80{ }^{\circ} \mathrm{C}$ for $120 \mathrm{~min}$ in $\left.\mathrm{THF}\right)$.

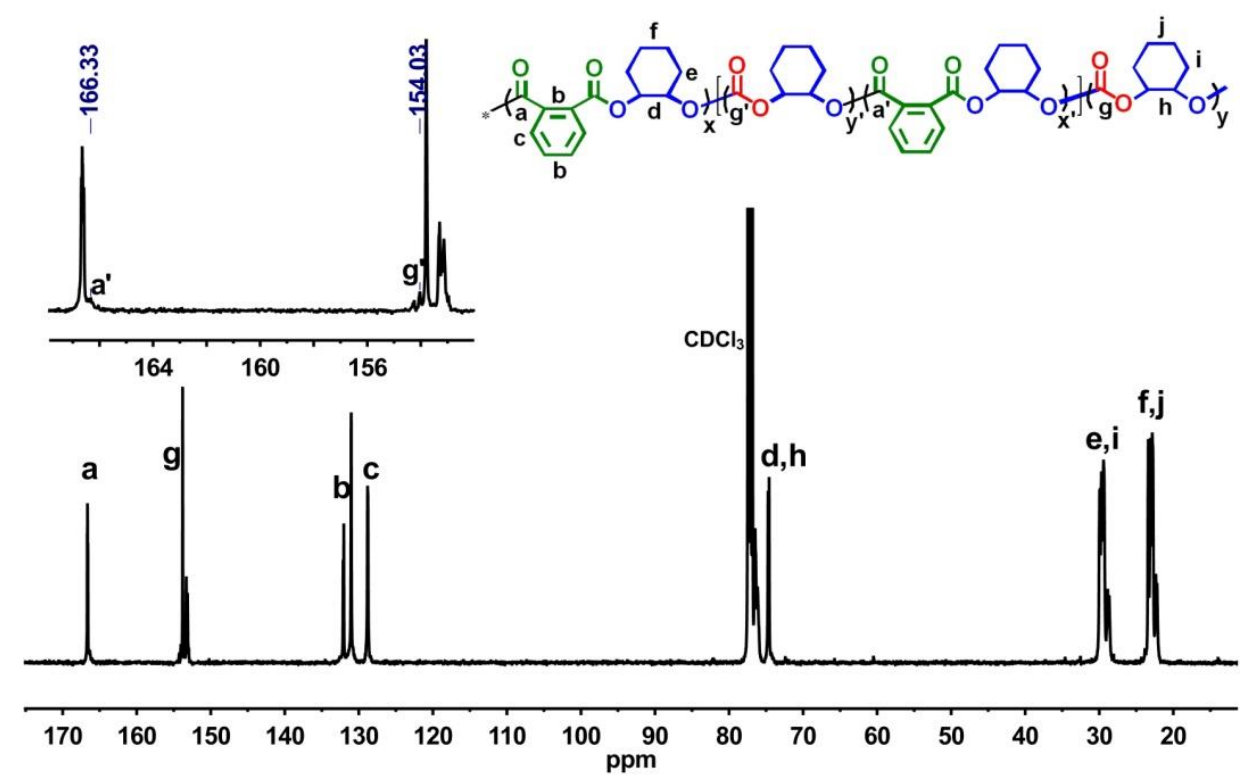

Figure S12. ${ }^{13} \mathrm{C}$ NMR spectrum $\left(\mathrm{CDCl}_{3}\right)$ of poly(PA-alt-CHO)-b-PCHC obtained in the one-step route (Table 1 run 10). 

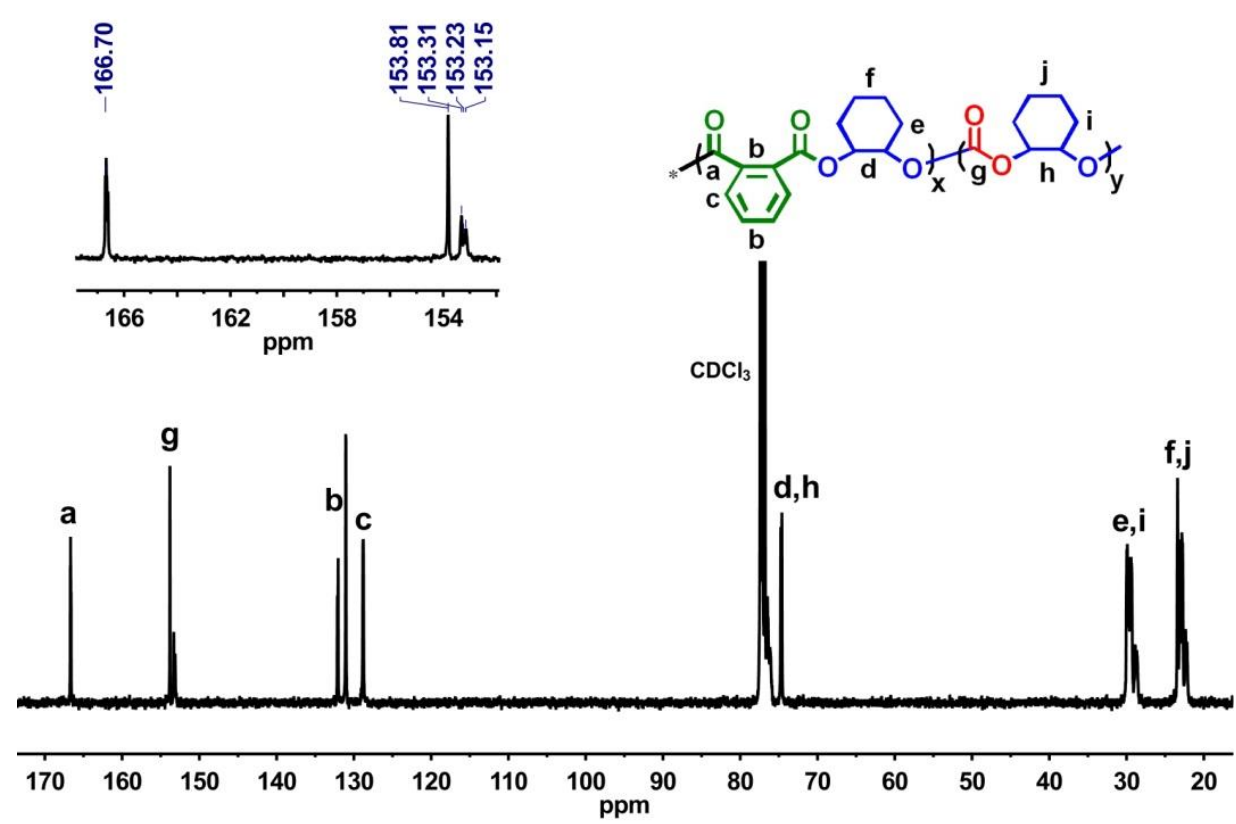

Figure S13. ${ }^{13} \mathrm{C}$ NMR spectrum $\left(\mathrm{CDCl}_{3}\right)$ of poly(PA-alt-CHO)- $b$-PCHC obtained in the sequential route (Table 2 run 2).
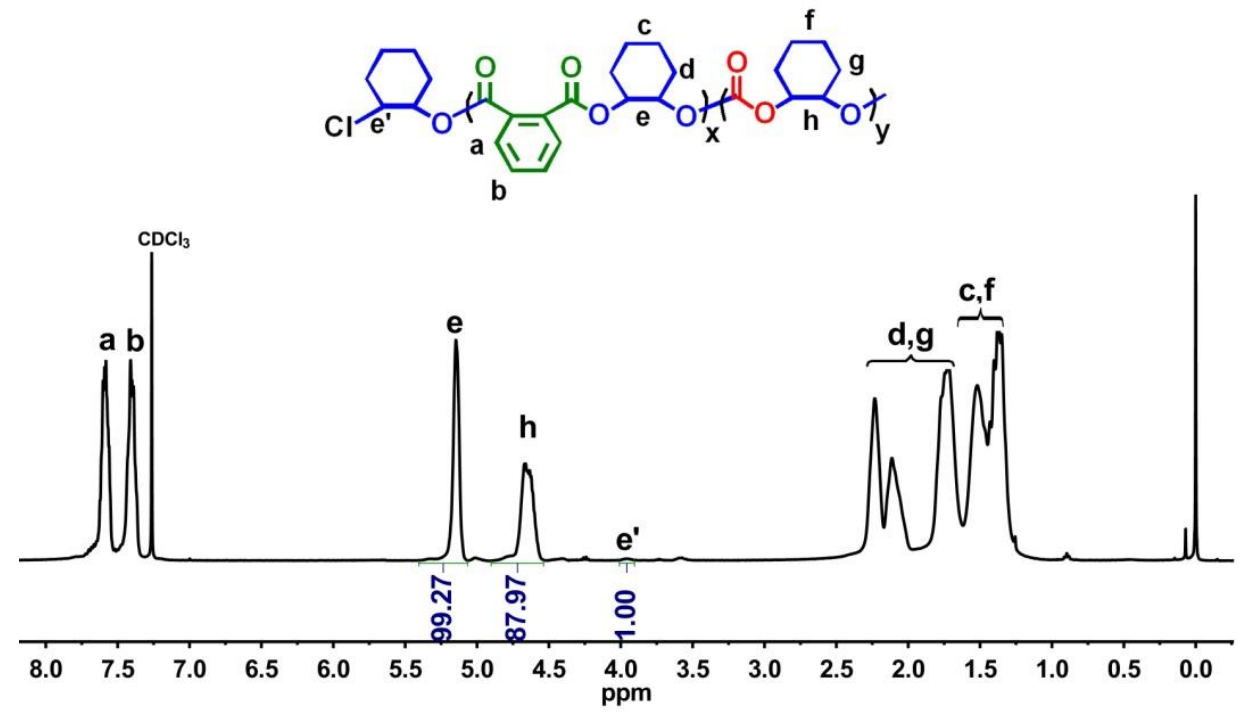

Figure S14. ${ }^{1} \mathrm{H}$ NMR spectrum $\left(\mathrm{CDCl}_{3}\right)$ of poly(PA-alt-CHO)-b-PCHC obtained in Table 2 run 1. 


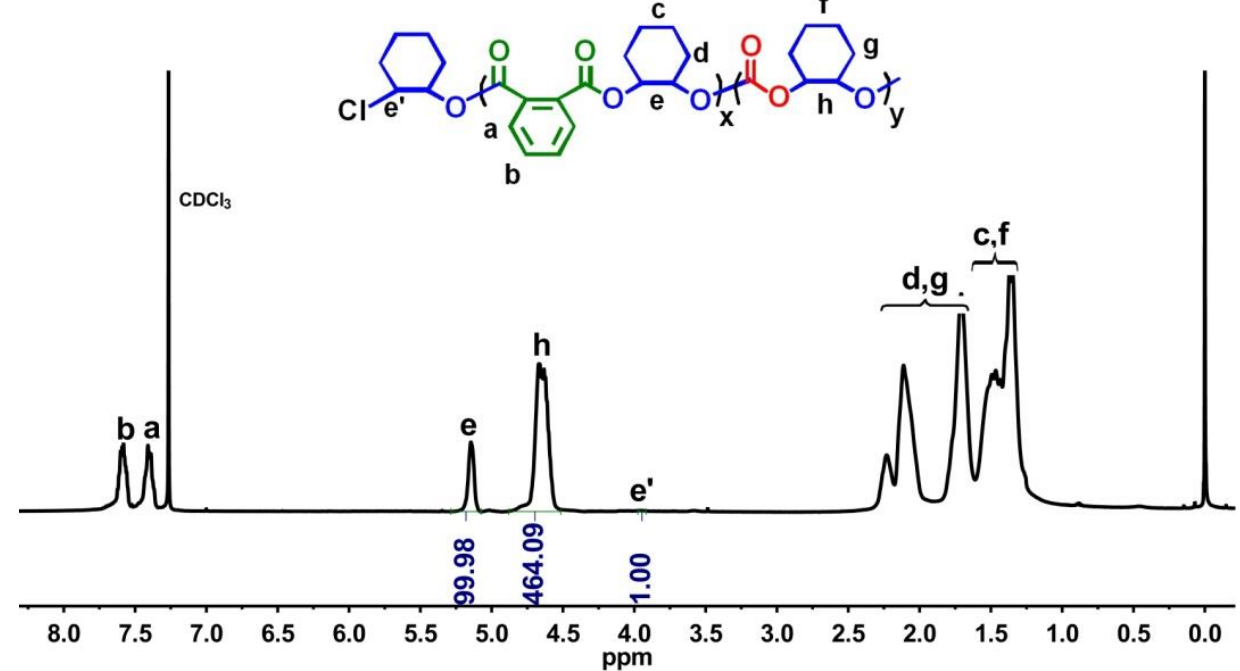

Figure S15. ${ }^{1} \mathrm{H}$ NMR spectrum $\left(\mathrm{CDCl}_{3}\right)$ of poly(PA-alt-CHO)-b-PCHC obtained in Table 2 run 3.

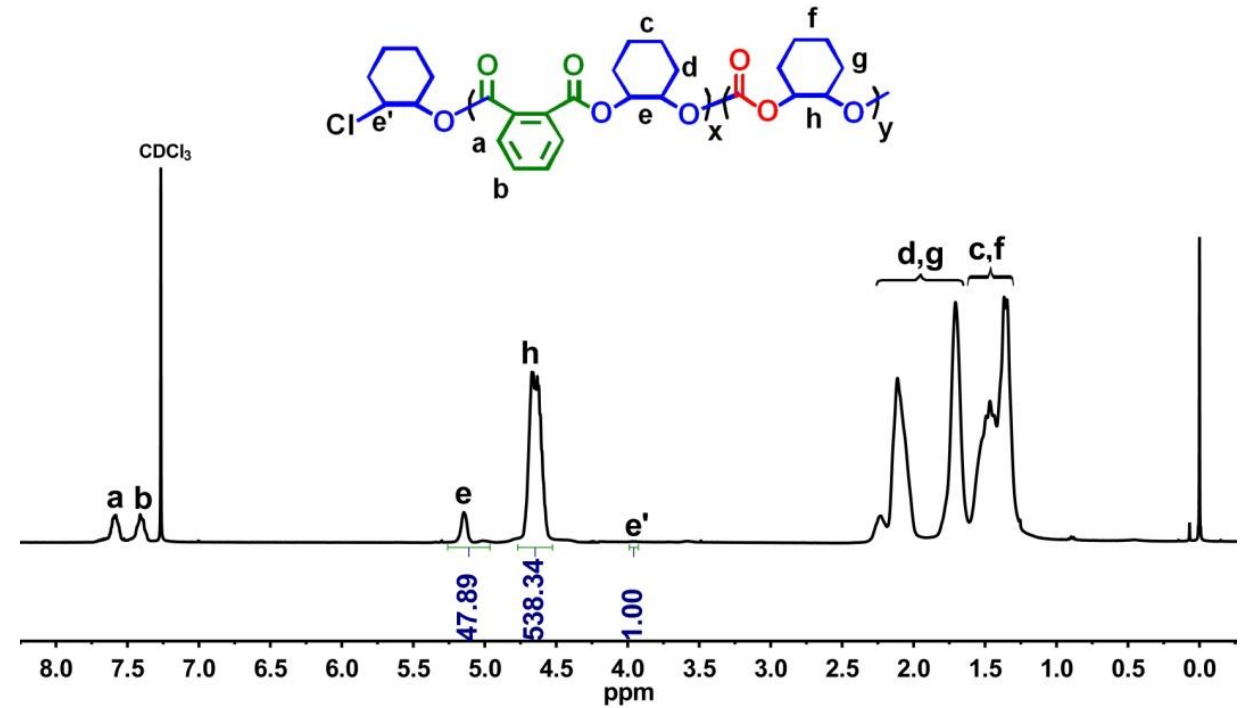

Figure S16. ${ }^{1} \mathrm{H}$ NMR spectrum $\left(\mathrm{CDCl}_{3}\right)$ of poly(PA-alt-CHO)-b-PCHC obtained in Table 2 run 4. 


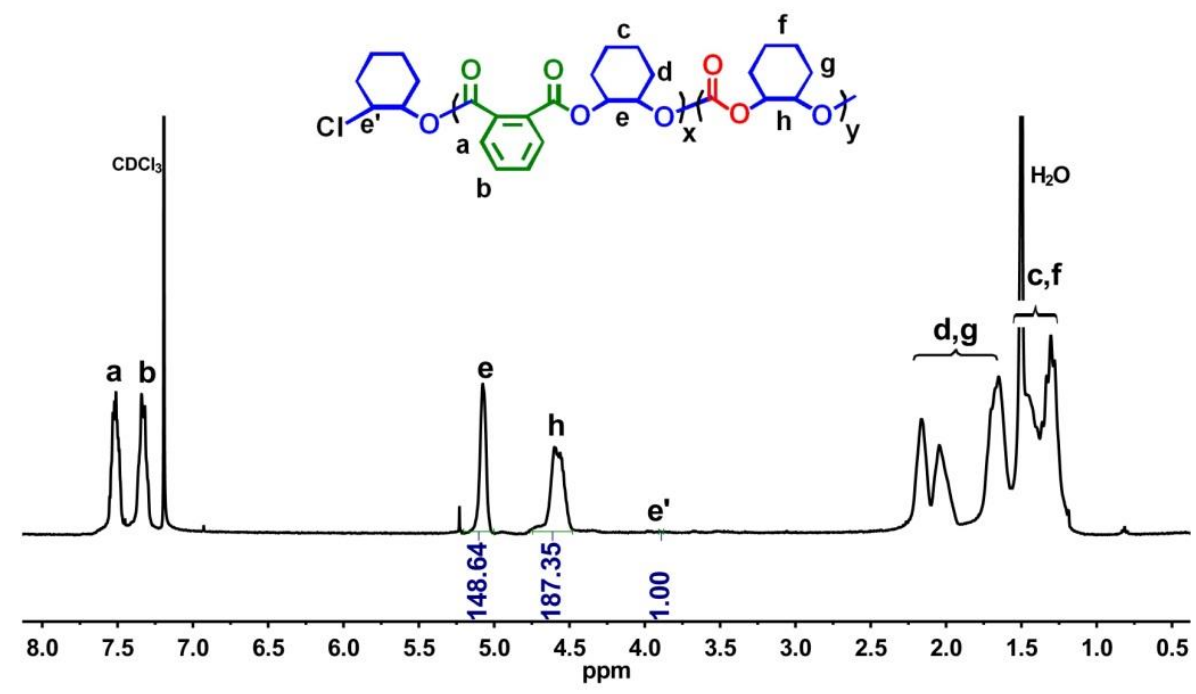

Figure S17. ${ }^{1} \mathrm{H}$ NMR spectrum $\left(\mathrm{CDCl}_{3}\right)$ of poly(PA-alt-CHO)-b-PCHC obtained in Table 2 run 5.

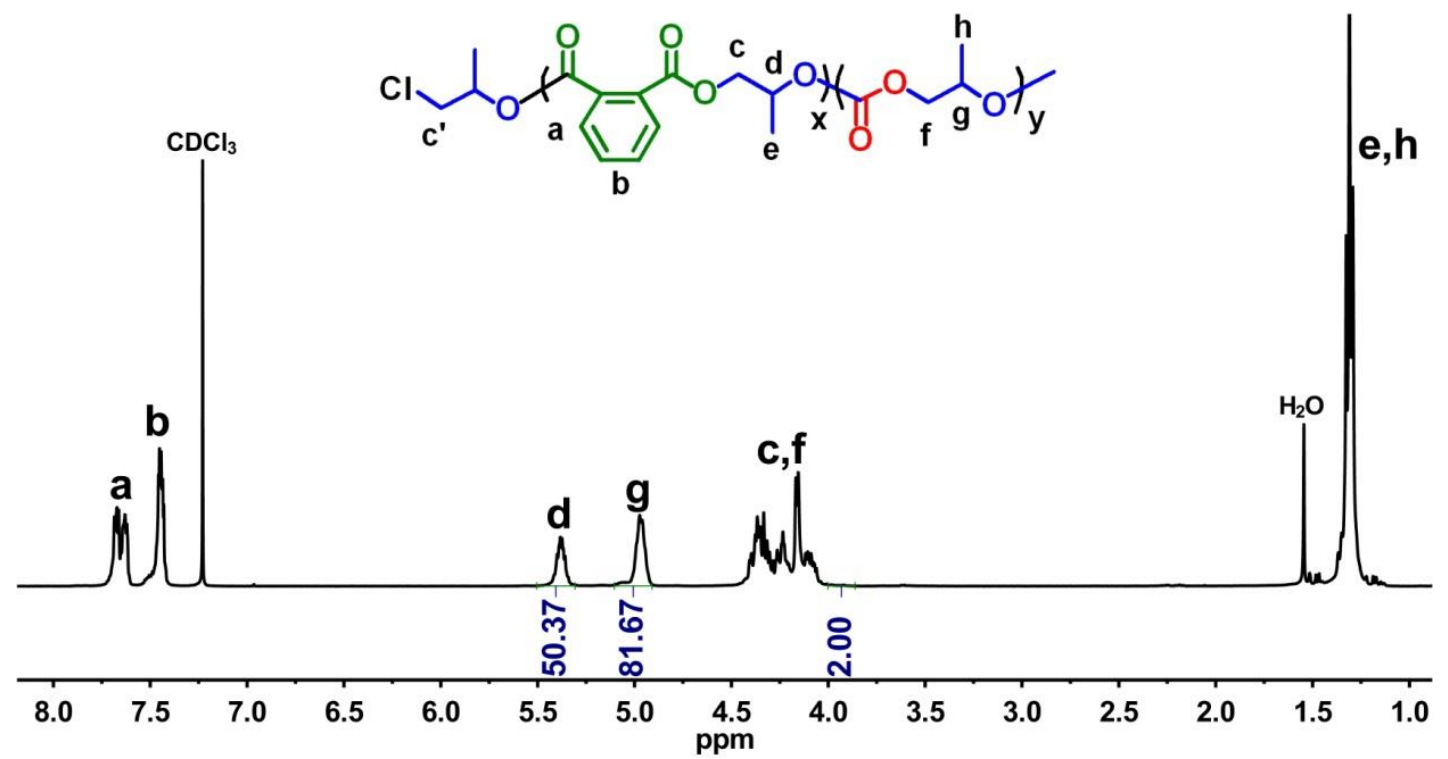

Figure S18. ${ }^{1} \mathrm{H}$ NMR spectrum $\left(\mathrm{CDCl}_{3}\right)$ of poly(PA-alt-PO)- $b$-PPC (Table 2 run 7). 


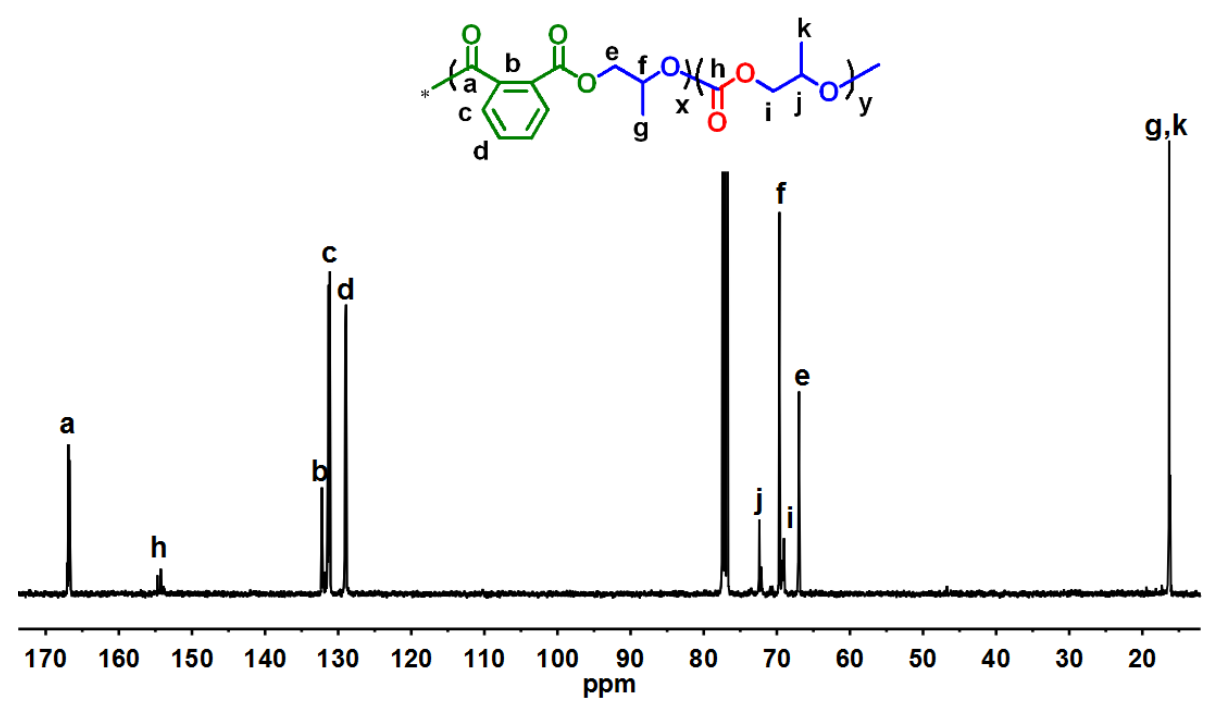

Figure S19. ${ }^{13} \mathrm{C}$ NMR spectrum $\left(\mathrm{CDCl}_{3}\right)$ of poly(PA-alt-PO)- $b$-PPC (Table 2 run 7$)$.

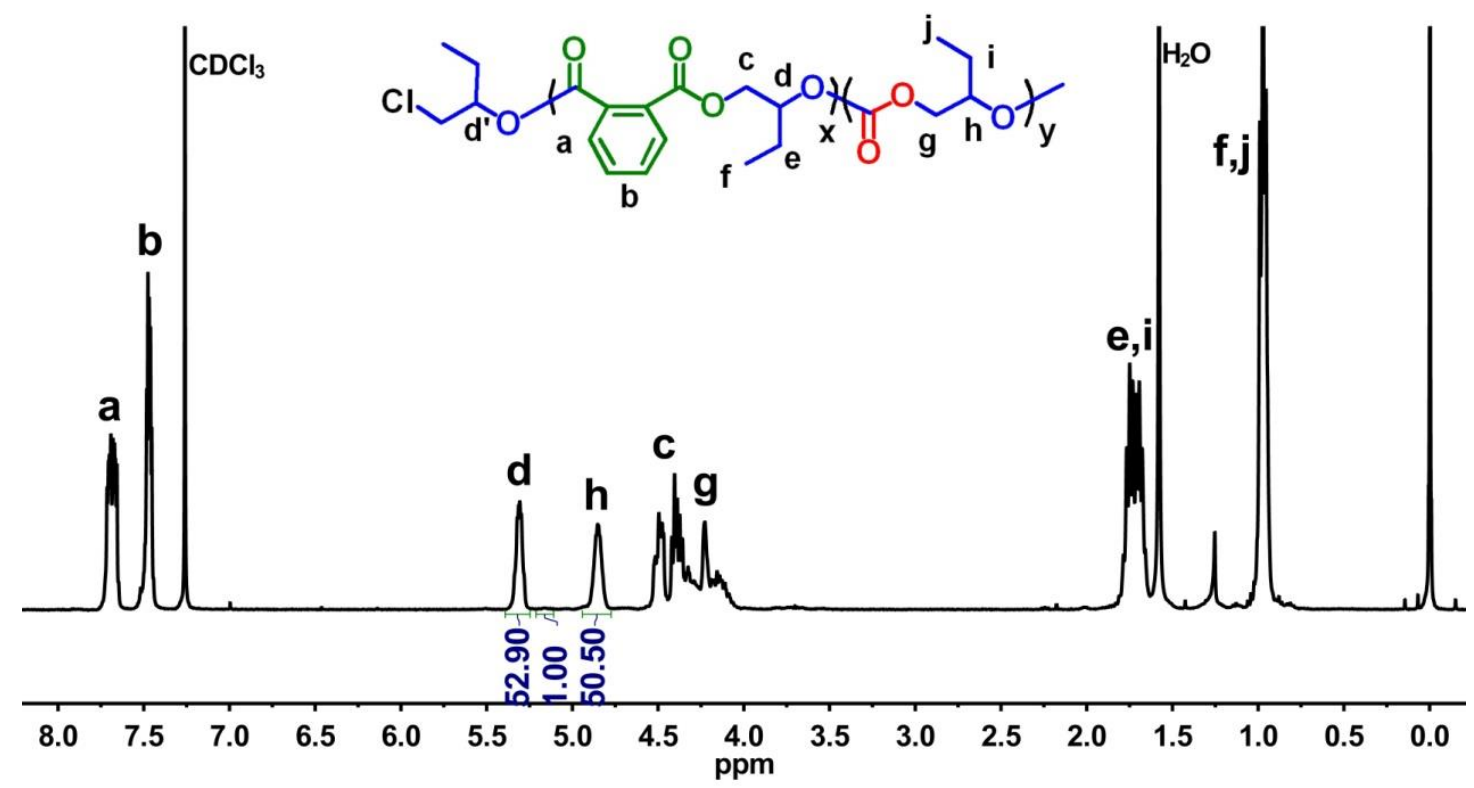

Figure S20. ${ }^{1} \mathrm{H}$ NMR spectrum $\left(\mathrm{CDCl}_{3}\right)$ of poly(PA-alt-BO)- $b$-PBC (Table 2 run 9). 


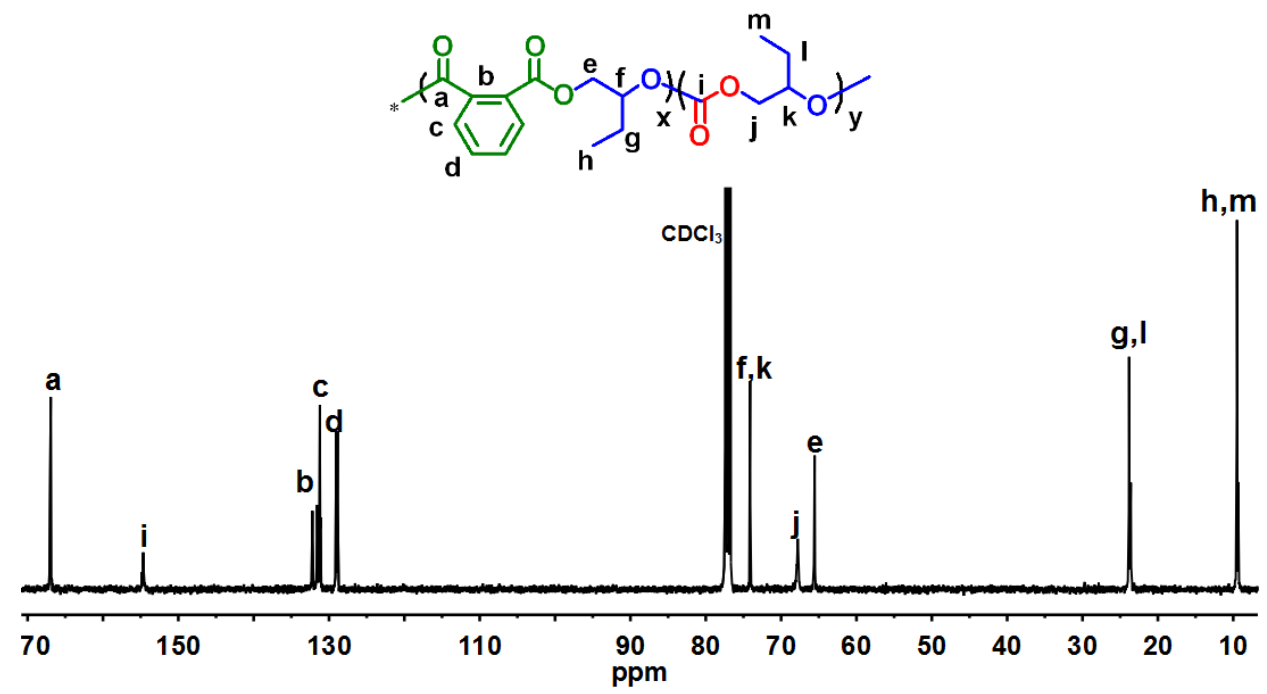

Figure S21. ${ }^{13} \mathrm{C}$ NMR spectrum $\left(\mathrm{CDCl}_{3}\right)$ of poly(PA-alt-BO)- $b$-PBC (Table 2 run 9).

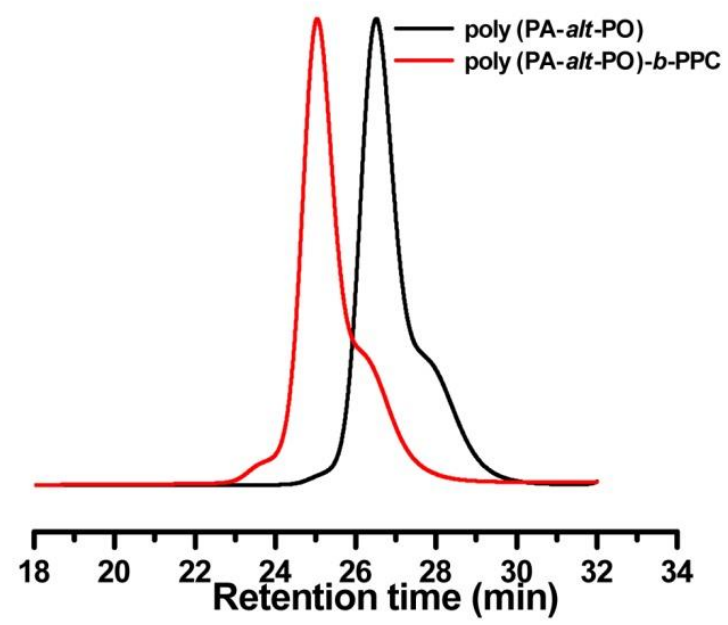

Figure S22. GPC traces of poly(PA-alt-PO) (black line, Table 2 run 6) and poly(PA-alt-PO)-b-PPC (red line, Table 2 run 7). 


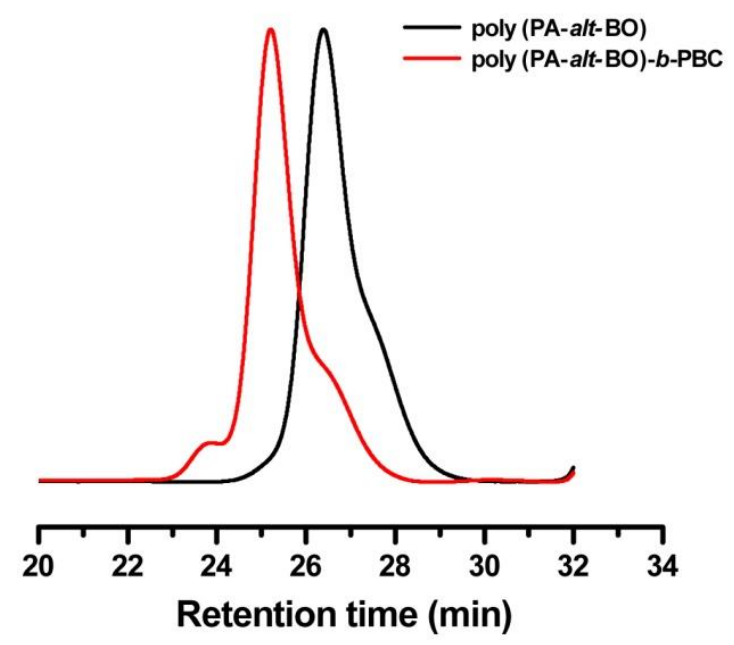

Figure S23. GPC traces of $\mathrm{P}(\mathrm{PA}-$ alt-BO) (black line, Table 2 run 8 ) and poly(PA-alt-BO)- $b$-PBC (red line, Table 2 run 9).

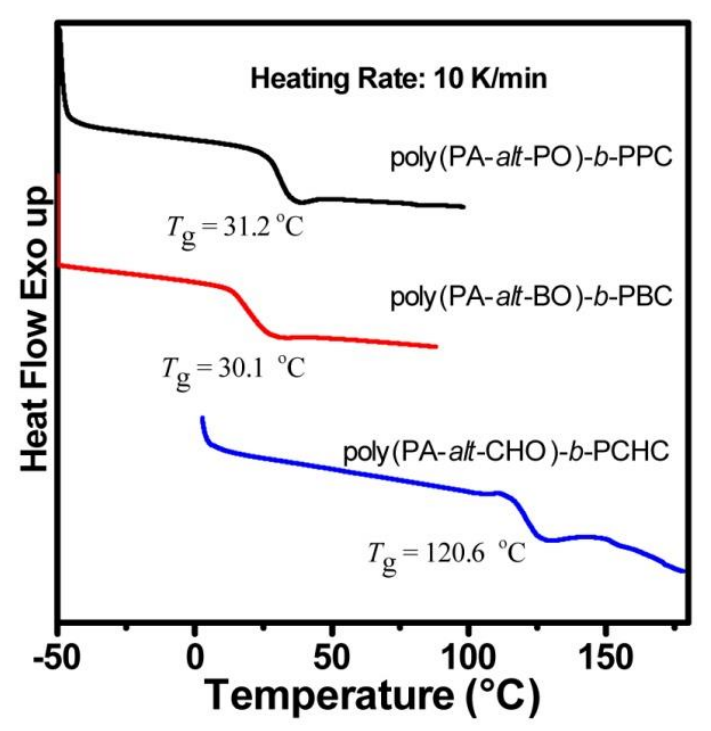

Figure S24. DSC traces (second heating runs) of poly(PA-alt-CHO)- $b$-PCHC, poly(PA-alt-PO)- $b$-PPC and poly(PA-alt-BO)- $b$-PBC obtained in Table 2 run 2 , and Table 2 runs 7 and 9. 


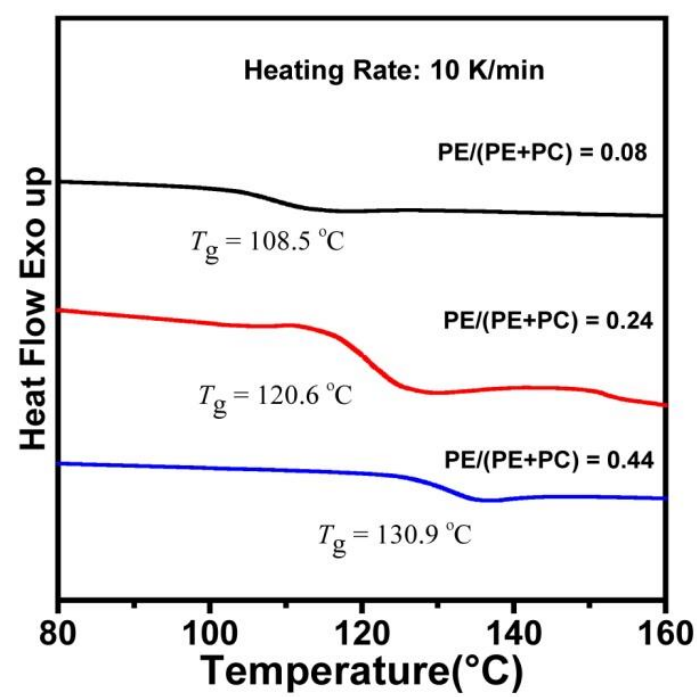

Figure S25. DSC traces (second heating runs) of poly(PA-alt-CHO)- $b$-PCHC with different contains poly(PA-alt-CHO) in Table 2 runs 2, 4-5. 


\section{Computational Details}

In present work, all quantum chemical computations were performed by using the Gaussian 16 package of programs. ${ }^{1}$ Each optimized structure was optimized with $\omega \mathrm{B} 97 \mathrm{XD}{ }^{2,3} / \mathrm{BSI}$ and was subsequently characterized as a minimum $(\mathrm{Nimag}=0)$ or a transition state $($ Nimag $=1)$ by harmonic vibration frequencies which providing thermodynamic data. The transition state structures are shown to connect the reactant and product on either side via intrinsic reaction coordinate (IRC) following. In the BSI, C and $\mathrm{H}$ atoms in gray part (Figure S24) of PPNCI were considered by 3-21G basis set, the other $\mathrm{C}, \mathrm{H}, \mathrm{O}, \mathrm{N}, \mathrm{B}, \mathrm{P}$, and $\mathrm{Cl}$ atoms were calculated by the $6-31 \mathrm{G}^{*}$ basis set. To obtain more reliable relative energies, the single-point calculations of optimized structures were carried out at the level of $\omega \mathrm{B} 97 \mathrm{XD} / 6-311+\mathrm{G}^{* *}$. Therefore, unless otherwise mentioned, the free energy $(\Delta \mathrm{G}, 298.15 \mathrm{~K}, 1 \mathrm{~atm})$, which was used for description of energy profiles, was obtained from the single-point calculation and the gas-phase Gibbs free energy correction.

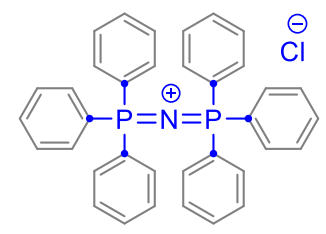

Figure S24. The structure of complex PPNCI. 


\section{References}

(1) Frisch, M. J. T.; G. W.; Schlegel, H. B.; Scuseria, G. E.; Robb, M. A.; Cheeseman, J. R.; Scalmani, G.; Barone, V.; Mennucci, B.; Petersson, G. A.; Nakatsuji, H.; Caricato, M.; Li, X.; Hratchian, H. P.; Izmaylov, A. F.; Bloino, J.; Zheng, G.; Sonnenberg, J. L.; Hada, M.; Ehara, M.; Toyota, K.; Fukuda, R.; Hasegawa, J.; Ishida, M.; Nakajima, T.; Honda, Y.; Kitao, O.; Nakai, H.; Vreven, T.; Montgomery, J. A., Jr.; Peralta, J. E.; Ogliaro, F.; Bearpark, M.; Heyd, J. J.; Brothers, E.; Kudin, K. N.; Staroverov, V. N.; Kobayashi, R.; Normand, J.; Raghavachari, K.; Rendell, A.; Burant, J. C.; Iyengar, S. S.; Tomasi, J.; Cossi, M.; Rega, N.; Millam, N. J.; Klene, M.; Knox, J. E.; Cross, J. B.; Bakken, V.; Adamo, C.; Jaramillo, J.; Gomperts, R.; Stratmann, R. E.; Yazyev, O.; Austin, A. J.; Cammi, R.; Pomelli, C.; Ochterski, J. W.; Martin, R. L.; Morokuma, K.; Zakrzewski, V. G.; Voth, G. A.; Salvador, P.; Dannenberg, J. J.;

Dapprich, S.; Daniels, A. D.; Farkas, Ö.; Foresman, J. B.; Ortiz, J. V.; Cioslowski, J.; Fox, D. J. Gaussian 16, Revision C.01; Gaussian, Inc.: Wallingford, CT, 2016.

(2) J.-D. Chai, M. Head-Gordon, J. Chem. Phys. 2008, 128, 084106.

(3) J.-D. Chai, M. Head-Gordon, Phys. Chem. Chem. Phys. 2008, 10, 6615-6620. 